\title{
sciendo
}

DOI 10.2478/sbe-2019-0011

SBE no. 14(1) 2019

\section{A COMPARISON OF BUSINESS MANAGEMENT CHARACTERISTICS IN U.S., GERMAN, AND JAPANESE MANUFACTURING CORPORATIONS}

\author{
MERIC Gulser \\ Rohrer College of Business, Rowan University, USA \\ GUNER Berrin \\ Rohrer College of Business, Rowan University, USA \\ CHUNG Shifei \\ Rohrer College of Business, Rowan University, USA \\ MERIC Ilhan \\ College of Business Administration, Rider University, USA
}

\begin{abstract}
:
Comparing the management characteristics of business firms in different countries has been a popular research topic in business administration. In this paper, we compare the management characteristics of U.S., German, and Japanese manufacturing corporations. The findings of our study can provide valuable insights for corporate managers and global investors. We find that U.S. manufacturing corporations have the lowest liquidity risk (i.e., U.S. manufacturing firms have higher liquidity levels) compared with German and Japanese manufacturing corporations. German manufacturing corporations have the highest bankruptcy risk (i.e., German manufacturing firms have higher liability levels) compared with U.S. and Japanese manufacturing corporations. The average collection period of accounts receivable and the average payment period of accounts payable are significantly shorter in U.S. manufacturing corporations compared with their German and Japanese counterparts. Due to the extensive use of the just-in-time inventory management system in Japanese Keiretsu industry groupings, Japanese manufacturing corporations have higher inventory turnover rates (i.e., Japanese manufacturing corporations carry lower inventory levels) compared with U.S. and German manufacturing corporations. U.S. manufacturing corporations are able to earn higher operating profit margins compared with their German and Japanese counterparts because they are able to charge higher product prices to customers and/or they are able to have lower manufacturing costs. Japanese manufacturing corporations have the lowest annual sales and total assets growth rates compared with U.S. and German manufacturing corporations.
\end{abstract}

Key words: Business management characteristics; U.S., German, and Japanese manufacturing corporations; MANOVA (Multivariate Analysis of Variance) 


\section{Introduction}

Comparing the characteristics of different groups of business firms has long been a popular research topic. Altman (1968), Beaver (1968), Deakin (1972), Moyer (1977), Edmister (1972), and Dambolena and Khoury (1980) predict bankruptcy by comparing the business characteristics of bankrupt and non-bankrupt firms. Stevens (1973), Belkaoui (1978), Rege (1984), and Meric at al. (1991) identify the characteristics of firms that have been corporate takeover targets by comparing them with firms that have not been corporate takeover targets. Hutchinson at al. (1988) and Meric and Meric (1992) identify the characteristics of firms which achieve stock market quotation by comparing them with firms that do not have stock market quotation. Meric at al. (2000) compare Japanese keiretsu-affiliated and independent firms to identify the characteristics of keiretsu-affiliated firms.

A number of studies compare the financial characteristics of business firms in different countries. Kester (1986) and Wald (1999) compare the capital and ownership structures of firms in different countries and they find significant differences. Meric and Meric (1989 and 1994) compare the financial characteristics of U.S. and Japanese manufacturing firms and they find significant differences. Meric et al. (2003) find significant differences between the financial characteristics of U.S. and Canadian manufacturing firms. Meric et al. (2016) find significant differences between the financial characteristics of U.S. and European manufacturing firms.

In this paper, we compare the business management characteristics of U.S., German, and Japanese manufacturing corporations. The findings of our study may provide valuable insights for corporate managers and global investors.

\section{A Comparison of U.S., German, and Japanese Accounting Systems}

The U.S. capital market is very active and equity-financing dominates the capital structures of most corporations. In the German and Japanese markets, debt-financing, primarily from large lending institutions, are more common. These institutions of Germany and Japan also maintain a close relationship with the companies they finance and presumably they do not have to rely on the published financial statements as a major source of information on the financial positions of the companies they finance. Hence the nature of the financial reporting process differs dramatically in the U.S. compared to that of German and Japanese markets. Typically, this means that accounting choices under the U.S. standards are more restrictive and conservative compared to the other two markets.

\section{Accounting in the U.S.}

Corporations in the U.S. follow standards set by the Financial Accounting Standards Board (FASB) and the public companies are subject to rules of the Securities and Exchange Commission (SEC) who has the statutory authority to enforce the rules on them. All public companies have to file annual financial statements with the SEC and these 
annual reports have to be prepared under the standards of the FASB (U.S. generally accepted accounting principles or U.S. GAAPs). Foreign corporations who list on U.S. stock exchanges have to file annual reports with the SEC and if these are prepared using foreign accounting standards, then a reconciliation of the statements to U.S. GAAPs is necessary. However, a reconciliation is not required if the financial statements are prepared using International Financial Reporting Standards (IFRS), standards set by the International Accounting Standards Board (IASB) which are used globally in many countries. For foreign corporations, the SEC accepts financial statements filed with them using IFRS. Nevertheless, domestic U.S. companies are not allowed to use IFRS as an alternative to U.S. GAAPs.

There are significant differences between U.S. GAAPs and IFRS. For example, one fundamental difference between the two standards is with respect to inventory valuation. U.S GAAPs permits the use of the Last-In First-Out (LIFO) method to account for inventory, whereas it is not permissible in IFRS. The reason is LIFO can provide an inaccurate appraisal of stock leading to low-income levels. These differences can be quite significant in a highly inflationary environment or with the types of products whose value decline (or fluctuate) substantially over time, such as technology products. Another important difference concerning inventory valuation between the two systems is in the reversals. U.S GAAPs does not allow inventory reversals once they are written down. However, this is permissible under IFRS, provided it meets the required criteria (Herbei, 2015, p. 25).

The treatment of assets may also be different between the two systems. Under U.S GAAPs, fixed assets such as property, plant and equipment are valued using the cost model. Under the cost model, assets are valued at net book value, which is equal to its historical cost less accumulated depreciation over the life of the asset. However according to IFRS, fixed assets can also be valued using the revaluation model. The revaluation model can be referred to as the "mark-to-market approach" or "fair value" method of asset valuation. Under the revaluation model, assets are carried at a revalued amount provided its fair value can be measured reliably. This revalued amount is equal to its Fair value at the date of revaluation, less any subsequent accumulated depreciation, and less any subsequent accumulated impairment losses.

\section{Accounting in Germany}

Listed corporations in Germany have to prepare financial statements using IFRS, while non-listed companies have the option of preparing financial statements using either local German GAAPs or IFRS. Local German GAAPs are set by The Accounting Standards Committee of Germany (ASCG) which was established in 1998. The ASCG is a registered, not-for-profit association domiciled in Berlin. The objectives of the Association are to develop recommendations for the application of principles for consolidated financial reporting, to provide advice on planned legislation on accounting regulations at national and EU level, and to represent the Federal Republic of Germany in international accounting and financial reporting bodies. As discussed earlier, debt financing is an essential element of the capital structure of most German corporations and creditor protection is a fundamental concern of German accounting as embodied in the 
Commercial Code. Conservative balance sheet valuations are crucial to creditor protection. Therefore, there is a tendency to undervalue assets and overvalue liabilities. In addition, reserves are seen as protection against unforeseen risks and possible insolvency. Under German GAAPs provisions for estimates of future expenses or losses are used a lot. For instance, provisions are required to be set up for deferred maintenance expenses, product guarantees, potential losses from pending transactions, and other uncertain liabilities. Optional provisions, such as those for future major repairs, are also allowed. These practices result in a conservative income amount that serves as the basis for dividends to owners. Thus, German accounting is designed to report conservative income amounts that leave creditors protected after distributions are made to owners.

There are several important differences between the IFRS and the German GAAPs. While historical costs represent the basis of accounting for both systems, the IFRS allows the revaluation of the intangible and fixed assets, but German GAAPs does not permit revaluation. German GAAPs provides an exemption applicable to financial institutions. German GAAPs specify that if the financial statements do not present a true image of the business, the representatives of the company will have to disclose additional information through other documents as well. German GAAPs, like U.S., allows for the use of LIFO in inventory cost-flows, which is not permissible under IFRS. German GAAP requires a management report to be included in the annual report, which is an important part of a company's financial statements according to German tradition. In contrast, IFRS does not have a specific requirement about management reports in financial statements.

\section{Accounting in Japan}

In Japan, financial statements are prepared in accordance with accounting principles generally accepted in Japan as issued by the Accounting Standards Board of Japan (ASBJ). However, for consolidated financial statements of listed corporations, the use of IFRS, Japan's Modified International Standards (JMIS), or US GAAP is also permitted. JMIS are the new set of accounting standards introduced by ASBJ in 2015. They are developed based on the endorsement process of accounting standards and interpretations issued by the IASB. Therefore, with the introduction of JMIS, there are four accounting standards that the listed companies in Japan may use. Although differences exist between Japanese GAAPs and IFRS, the differences are less significant than those that exist between U.S and German GAAPs and IFRS. Some of the choices under Japanese GAAPs include the fact that inventory must be valued at cost or the lower of cost or net realizable value. Acceptable cost-flow methods for inventory are FIFO and average costs methods, with the average cost method being the most popular choice, while the choice of LIFO was eliminated after 2010. Investments in securities are valued at market. Fixed assets are valued at cost. Fixed assets are also impairments tested, but unlike under IFRS, written down values cannot be recovered in future periods. Research and development costs are expensed when incurred. Legal reserves are required. Each year a company must allocate an amount equal to at least 10 percent of cash dividends and bonuses paid to directors and statutory auditors until the legal reserve reaches 25 percent of capital stock. Many of the accounting practices were implemented as a result of the accounting changes that were made in the late 1990s (Economist, 1999). These changes 
include requiring listed companies to report a statement of cash flows, valuing investments in securities at market rather than cost, and valuing inventory at the lower of cost or net realizable value rather than cost.

\section{A Comparison of U.S., German, and Japanese Economies}

The U.S., Japan, and Germany are among the largest economies in the world in terms of the GDP purchasing power parity, taking $2^{\text {nd }}, 5^{\text {th }}$, and $6^{\text {th }}$ spots. By nominal GDP, they are ranked $1^{\text {st }}, 3^{\text {rd }}$, and $4^{\text {th }}$. Together, they make up $8 \%$ of the world population, but control $22 \%$ of the world economy and account for $21 \%$ and $24 \%$ of the world exports and imports respectively. All three countries are expected to have a healthy growth rate in the coming years.

As the largest economy, the US is forecasted to grow 2.3\% in 2018 (IMF, 2018). The effect of the new tax policy is estimated to stimulate the economy through 2020 . The U.S. economy is heavily dependent on household consumption, which accounts for $69.1 \%$ of the total economic activity. The U.S. is recognized to be one of the top producers of technology, machinery, aerospace, and knowledge with a total of 589,410 patent applications (WTO, 2018). However, compared to Japan and Germany, the U.S. is heavily depended on services that controls $80.2 \%$ of the GDP. The US is the world's largest importer and $2^{\text {nd }}$ largest exporter.

Japan is recognized as one of the world's largest and most technologically advanced producers of motor vehicles, electronic equipment, and electronics. Undoubtedly, Japan is not too far behind the U.S. with 318,721 patent applications. Household consumption is responsible for $55.9 \%$ of the total Japanese economy. The economy is expected to grow $0.7 \%$ in 2018 escaping the prolonged negative growth over the last two decades due to strong fiscal policies, monetary easing, inward consumption, and supplementary budget (IMF, 2018). Manufacturing and services account for $29.7 \%$ and $69.3 \%$ of the economy respectively. Japan is the world's 4th largest exporter and importer.

Table 1: Comparison of the three Economies (2017 estimated)

\begin{tabular}{|l|c|c|c|c|c|c|}
\hline Country & Population & $\begin{array}{c}\text { Total GDP } \\
\text { (trillion) }\end{array}$ & $\begin{array}{c}\text { Per Capita } \\
\text { GDP }\end{array}$ & $\begin{array}{c}\text { Unemployment } \\
\text { Rate }\end{array}$ & $\begin{array}{c}\text { Inflation } \\
\text { Rate }\end{array}$ & $\begin{array}{c}\text { Total Debt } \\
\text { (trillion) }\end{array}$ \\
\hline U.S. & $326,625,791$ & $\$ 19.36$ & $\$ 59,500$ & $4.4 \%$ & $2.1 \%$ & $\$ 17.91$ \\
\hline Germany & $80,594,017$ & $\$ 3.65$ & $\$ 50,200$ & $3.8 \%$ & $1.6 \%$ & $\$ 5.33$ \\
\hline Japan & $126,451,398$ & $\$ 4.88$ & $\$ 42,700$ & $2.9 \%$ & $0.4 \%$ & $\$ 3.24$ \\
\hline
\end{tabular}

Source: CIA World Fact book, 2018 (https://www.cia.gov/library/publications/resources/the-world-factbook)

Finally, as a strong global contributor of iron, steel, machinery, automobile, and electronics manufacturing, Germany is expected to continue with a strong economy. In 2018 , Germany is forecasted to have a $1.8 \%$ growth reflecting the stronger momentum in domestic as well as higher external demand. Through strong exports and savings, Germany was able to mitigate the economic ills that its other EU partners experienced. The GDP composition is similar to that of Japan. Germany is the world's $3^{\text {rd }}$ largest exporter and importer. 
Table 2: Comparison of the International Trades of the Three Countries

\begin{tabular}{|l|c|c|c|c|c|}
\hline Country & $\begin{array}{c}\text { Exports } \\
\text { (trillion) }\end{array}$ & $\begin{array}{c}\text { Imports } \\
\text { (trillion) }\end{array}$ & $\begin{array}{c}\text { Trade as \% } \\
\text { of GDP }\end{array}$ & $\begin{array}{c}\text { Share in the } \\
\text { world exports* }\end{array}$ & $\begin{array}{c}\text { Share in the } \\
\text { world imports* }\end{array}$ \\
\hline U.S. & $\$ 1.576$ & $\$ 2.352$ & 13.9 & $9.12 \%$ & $13.88 \%$ \\
\hline Germany & $\$ 1.401$ & $\$ 1.104$ & 42.4 & $8.40 \%$ & $6.50 \%$ \\
\hline Japan & $\$ 0.683$ & $\$ 625.7$ & 17.7 & $4.04 \%$ & $3.74 \%$ \\
\hline
\end{tabular}

Source: World Trade Organization

* Merchandise trade

\section{Methodology and Data}

Multiple Discriminant Analysis - MDA (see, e.g., Altman, 1968; Stevens, 1973; Belkaoui, 1978) and Multivariate Analysis of Variance - MANOVA (see, e.g., Hutchinson et al., 1988; Meric et al., 1991) are the two multivariate techniques most commonly used in previous studies to compare the business management characteristics of different groups of firms. In this study, we use the MANOVA technique to compare the business management characteristics of U.S., German, and Japanese manufacturing corporations. Detailed information about the MANOVA technique can be found in Marascuilo and Levin (1983) and Johnson and Wichern (2007).

The data used in the study were obtained from the Research Insight/Global Vintage database in October 2017. Manufacturing industries with SIC codes between 2000-3999 are covered in the study. The study includes all manufacturing corporations in the database with no missing information. To help avoid outliers distorting the MANOVA comparisons, following previous studies, the data were winsorized at both ends at the 2.5 percent level (see Gadarowski et al., 2007, and Wang et al, 2009). Our sample contains 683 U.S. manufacturing corporations, 167 German manufacturing corporations, and 1,440 Japanese manufacturing corporations, We use the variables presented in Table 3 as measures of business management characteristics in the comparisons.

Table 3: Variables Used in the Study as Measures of Business Management Characteristics

\begin{tabular}{ll}
\hline Variable & Definition \\
\hline $\begin{array}{l}\text { Liquidity } \\
\text { Current Ratio } \\
\text { Quick (Acid-Test) Ratio }\end{array}$ & $\begin{array}{l}\text { Current Assets / Current Liabilities } \\
\text { (Current Assets - Inventories) / Current Liabilities }\end{array}$ \\
$\begin{array}{l}\text { Asset Management } \\
\text { Average Receivables Collection Period }\end{array}$ & Accounts Receivable / Daily Credit Sales \\
Inventory Turnover & Sales / Inventories \\
Fixed Assets Turnover & Net Fixed Assets / Total Assets \\
Total Assets Turnover & Sales / Total Assets \\
Liability Management & \\
Average Payables Payment Period & Accounts Payable / Daily Credit Purchases \\
Equity/Liabilities Ratio & Common Equity / Total Liabilities \\
Profitability & Operating Profit / Sales \\
Operating Profit Margin & Net Income / Sales \\
Net Profit Margin & $-\mathbf{1 4 6}$ - \\
\hline
\end{tabular}


Return on Assets

Return on Equity

Growth

Sales Growth Rate

Total Assets Growth Rate
Net Income / Total Assets

Net Income / Common Equity

Annual Percentage Sales Growth Rate

Annual Percentage Total Assets Growth Rate

\section{Empirical Findings}

Our MANOVA test results are presented in Tables 4, 5, and 6. The multivariate Fvalue test statistics in the tables indicate that the overall financial characteristics of U.S., German, and

Japanese manufacturing corporations are significantly different at the 1-percent level. The univariate $\mathrm{F}$-value test statistics show that the business management characteristics of U.S., German, and Japanese manufacturing corporations are significantly different in terms of liquidity, asset management, liability management, profitability, and growth rates.

\section{Liquidity}

The liquidity ratios in the tables indicate that liquidity is significantly higher in U.S. manufacturing corporations than in German and Japanese manufacturing corporations (i.e., U.S. manufacturing corporations have significantly lower liquidity risk compared with German and Japanese manufacturing corporations). The current and acid-test (quick) ratios in Table 6 show that Japanese manufacturing corporations are significantly more liquid compared with German manufacturing corporations.

Table 4: MANOVA: U.S. vs. German Manufacturing Corporations

\begin{tabular}{|c|c|c|c|c|}
\hline \multirow[b]{2}{*}{ Financial Ratios } & \multicolumn{2}{|c|}{ Means and Standard Deviations $†$} & \multicolumn{2}{|c|}{ Univariate Statistics } \\
\hline & $\underline{\text { U.S. }}$. & German & F-Value & P-Value \\
\hline \multicolumn{5}{|l|}{ Liquidity } \\
\hline \multirow[t]{2}{*}{ Current Ratio } & 3.01 & 2.14 & $27.5^{\star \star}$ & 0.00 \\
\hline & (2.09) & $(1.04)$ & & \\
\hline \multirow[t]{2}{*}{ Quick (Acid-Test) Ratio } & 1.98 & 1.29 & $26.0^{* *}$ & 0.00 \\
\hline & (1.71) & $(0.76)$ & & \\
\hline \multicolumn{5}{|l|}{ Asset Management } \\
\hline \multirow{2}{*}{ Aver. Receivables Col. Period } & 52.9 & 62.0 & $20.9^{* *}$ & 0.00 \\
\hline & $(21.9)$ & $(26.8)$ & & \\
\hline \multirow{2}{*}{ Inventory Turnover } & 5.27 & 4.19 & $8.36^{* *}$ & 0.00 \\
\hline & $(4.47)$ & (3.73) & & \\
\hline \multirow[t]{2}{*}{ Fixed Assets Turnover } & 8.19 & 6.99 & 2.35 & 0.13 \\
\hline & $(9.27)$ & $(8.13)$ & & \\
\hline \multirow[t]{2}{*}{ Total Assets Turnover } & 1.00 & 1.14 & $13.1^{* *}$ & 0.00 \\
\hline & $(0.48)$ & $(0.45)$ & & \\
\hline \multicolumn{5}{|l|}{ Liability Management } \\
\hline \multirow[t]{2}{*}{ Aver. Payables Pay. Period } & 43.7 & 51.5 & $17.3^{\star \star}$ & 0.00 \\
\hline & (20.9) & (25.5) & & \\
\hline
\end{tabular}




\section{Studies in Business and Economics no. 14(1)/2019}

\begin{tabular}{|c|c|c|c|c|}
\hline Equity/Liabilities Ratio & $\begin{array}{c}1.80 \\
(2.26)\end{array}$ & $\begin{array}{c}1.12 \\
(0.93)\end{array}$ & $14.6^{* *}$ & 0.00 \\
\hline \multicolumn{5}{|l|}{ Profitability } \\
\hline Operating Profit Margin & $\begin{array}{c}9.98 \% \\
(9.95 \%)\end{array}$ & $\begin{array}{r}7.17 \% \\
(5.19 \%)\end{array}$ & $12.5^{\star *}$ & 0.00 \\
\hline Net Profit Margin & $\begin{array}{c}5.24 \% \\
(9.68 \%)\end{array}$ & $\begin{array}{c}4.51 \% \\
(4.28 \%)\end{array}$ & 0.91 & 0.34 \\
\hline Return on Assets & $\begin{array}{c}4.50 \% \\
(7.71 \%)\end{array}$ & $\begin{array}{r}4.73 \% \\
(4.68 \%)\end{array}$ & 0.14 & 0.71 \\
\hline Return on Equity & $\begin{array}{c}11.0 \% \\
(20.0 \%)\end{array}$ & $\begin{array}{c}10.0 \% \\
(8.48 \%)\end{array}$ & 0.38 & 0.54 \\
\hline \multicolumn{5}{|l|}{ Growth } \\
\hline Annual Sales Growth Rate & $\begin{array}{c}3.44 \% \\
(13.8 \%)\end{array}$ & $\begin{array}{c}5.51 \% \\
(7.50 \%)\end{array}$ & 3.49 & 0.06 \\
\hline Annual Tot. Assets Gro. Rate & $\begin{array}{c}6.89 \% \\
(17.1 \%) \\
\end{array}$ & $\begin{array}{r}6.43 \% \\
(7.86 \%) \\
\end{array}$ & 0.12 & 0.73 \\
\hline \multicolumn{3}{|c|}{ Multivariate Statistics: } & $11.6^{* \star}$ & 0.00 \\
\hline
\end{tabular}

\section{Asset Management}

U.S. manufacturing corporations are more efficient in collecting their accounts receivable compared with German and Japanese manufacturing corporations. The average collection period of accounts receivable is significantly shorter in U.S. manufacturing corporations than in German and Japanese manufacturing corporations. Japanese manufacturing corporations have the longest average collection period among the three countries.

The inventory turnover rate is significantly higher in Japanese manufacturing corporations than in U.S. and German manufacturing corporations (i.e., Japanese manufacturing corporations carry lower levels of inventories compared with U.S. and German manufacturing corporations). This may be due to the extensive use of the just-intime inventory system in the kerietsu industry groups. Inventory turnover rate is significantly higher in U.S. manufacturing corporations than in German manufacturing corporations. German manufacturing corporations have the lowest inventory turnover rates (i.e., German firms carry the largest levels of inventories) among the three countries.

Fixed assets turnover rate is significantly higher in U.S. manufacturing corporations than in Japanese manufacturing corporations. The average turnover rate is also higher in U.S. manufacturing corporations than in German manufacturing corporations and it is also higher in German manufacturing corporations than in Japanese manufacturing corporations. However, these differences are not statistically significant at the conventional 5 percent level. 
Table 5: MANOVA: U.S. vs. Japanese Manufacturing Corporations

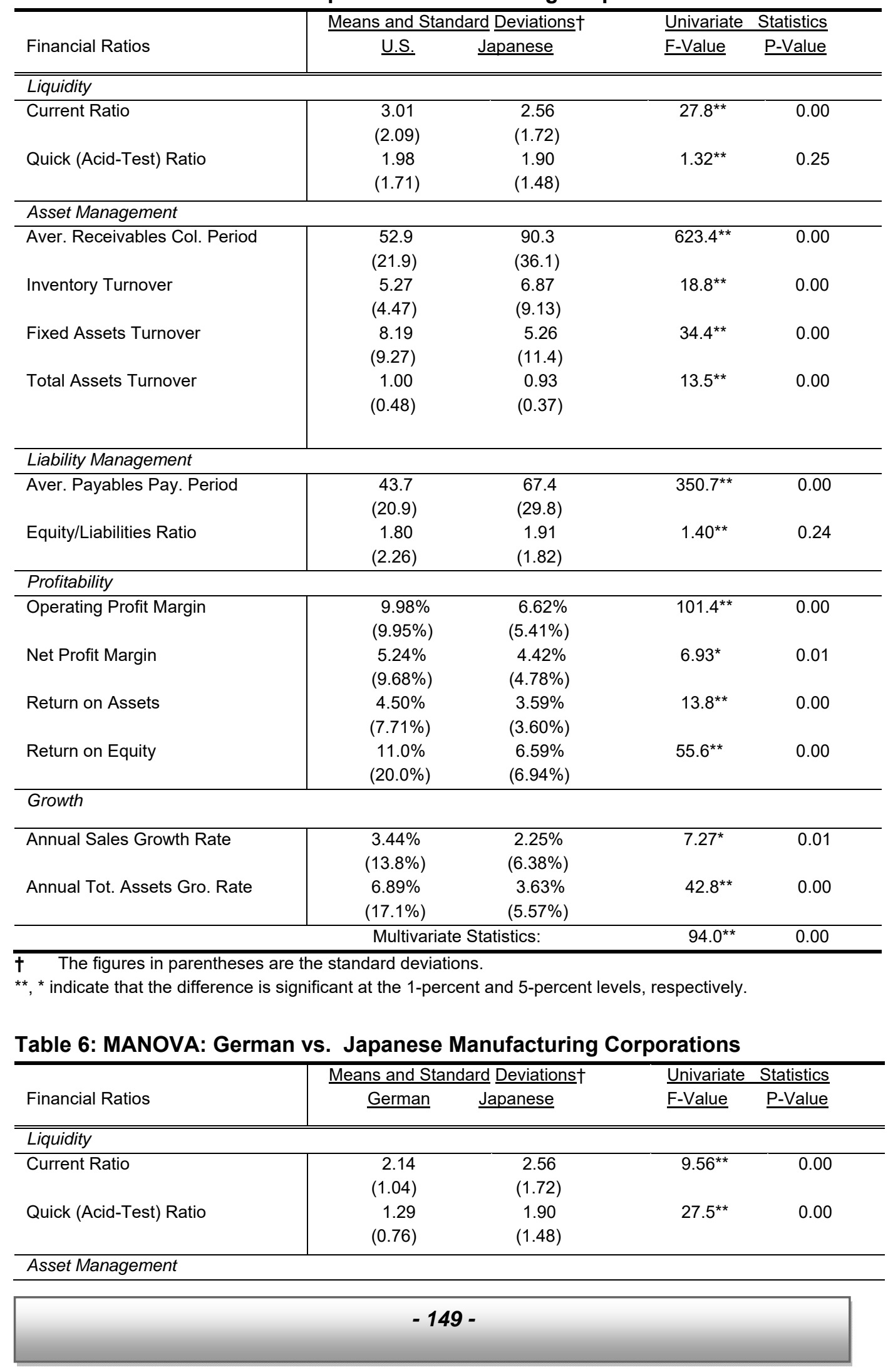




\section{Studies in Business and Economics no. 14(1)/2019}

\begin{tabular}{|c|c|c|c|c|}
\hline Aver. Receivables Col. Period & $\begin{array}{r}62.0 \\
(26.8)\end{array}$ & $\begin{array}{c}90.3 \\
(36.1)\end{array}$ & $96.5^{* *}$ & 0.00 \\
\hline Inventory Turnover & $\begin{array}{r}4.19 \\
(3.73)\end{array}$ & $\begin{array}{c}6.87 \\
(9.13)\end{array}$ & $14.1^{* *}$ & 0.00 \\
\hline Fixed Assets Turnover & $\begin{array}{c}6.99 \\
(8.13)\end{array}$ & $\begin{array}{c}5.26 \\
(11.4)\end{array}$ & 3.64 & 0.06 \\
\hline Total Assets Turnover & $\begin{array}{l}1.14 \\
(0.45)\end{array}$ & $\begin{array}{c}0.93 \\
(0.37)\end{array}$ & $50.2^{* *}$ & 0.00 \\
\hline Liability Management & & & & \\
\hline Aver. Payables Pay. Period & $\begin{array}{r}51.5 \\
(25.5)\end{array}$ & $\begin{array}{c}67.4 \\
(29.8)\end{array}$ & $43.5^{\star \star}$ & 0.00 \\
\hline Equity/Liabilities Ratio & $\begin{array}{c}1.12 \\
(0.93) \\
\end{array}$ & $\begin{array}{c}1.91 \\
(1.82) \\
\end{array}$ & $30.5^{\star *}$ & 0.00 \\
\hline Profitability & & & & \\
\hline Operating Profit Margin & $\begin{array}{c}7.17 \% \\
(5.19 \%)\end{array}$ & $\begin{array}{r}6.62 \% \\
(5.41 \%)\end{array}$ & 1.56 & 0.21 \\
\hline Net Profit Margin & $\begin{array}{c}4.51 \% \\
(4.28 \%)\end{array}$ & $\begin{array}{c}4.42 \% \\
(4.78 \%)\end{array}$ & 0.06 & 0.81 \\
\hline Return on Assets & $\begin{array}{c}4.73 \% \\
(4.68 \%)\end{array}$ & $\begin{array}{c}3.59 \% \\
(3.60 \%)\end{array}$ & $14.1^{* *}$ & 0.00 \\
\hline Return on Equity & $\begin{array}{c}10.0 \% \\
(8.48 \%)\end{array}$ & $\begin{array}{c}6.59 \% \\
(6.94 \%)\end{array}$ & $34.9^{* *}$ & 0.00 \\
\hline Growth & & & & \\
\hline Annual Sales Growth Rate & $\begin{array}{r}5.51 \% \\
(7.50 \%)\end{array}$ & $\begin{array}{c}2.25 \% \\
(6.38 \%)\end{array}$ & $37.5^{\star \star}$ & 0.00 \\
\hline Annual Tot. Assets Gro. Rate & $\begin{array}{r}6.43 \% \\
(7.86 \%) \\
\end{array}$ & $\begin{array}{r}3.63 \% \\
(5.57 \%) \\
\end{array}$ & $34.3^{* *}$ & 0.00 \\
\hline \multicolumn{3}{|c|}{ Multivariate Statistics: } & $19.9^{* *}$ & 0.00 \\
\hline
\end{tabular}

The total assets turnover rate is significantly higher in German manufacturing corporations than in U.S. and Japanese manufacturing corporations (i.e., German manufacturing corporations are able to generate more sales on their total assets compared with U.S. and German manufacturing corporations). The rate is significantly higher in U.S. manufacturing corporations than in Japanese manufacturing corporations. Japanese manufacturing corporations have the lowest total assets turnover rates among the three countries.

\section{Liability Management}

The average payment period of accounts payable is significantly shorter in U.S. manufacturing corporations than in German and Japanese manufacturing corporations. The average payment period is significantly longer in Japanese manufacturing corporations than in German manufacturing corporations. Japanese manufacturing corporations have the longest average payment period among the three countries.

The equity/liabilities ratios are significantly lower in German manufacturing corporations than in U.S. and Japanese manufacturing corporations (i.e., German manufacturing corporations have greater bankruptcy risk compares with U.S. and Japanese 
manufacturing corporations). The equity/liabilities ratio is not significantly different in U.S. and Japanese manufacturing corporations.

\section{Profitability}

Operating Profit margin is significantly higher in U.S. manufacturing corporations than in German and Japanese manufacturing corporations. This implies that U.S. manufacturing corporations are able to charge higher product prices to their customers and/or they have lower operating costs compared with German and Japanese manufacturing corporations. Operating Profit margin is not significantly different in German and Japanese manufacturing corporations.

Net profit margin is significantly higher in U.S. manufacturing corporations than in Japanese manufacturing corporations. The average is higher in U.S. manufacturing corporations than in German manufacturing corporations and higher in German manufacturing corporations than in Japanese manufacturing corporations. However, these differences are not statistically significant.

Return on assets and return on equity are significantly higher in U.S. and German manufacturing corporations than in Japanese manufacturing corporations. However, the differences are not statistically significant in U.S. and German manufacturing corporations.

\section{Growth}

Annual sales and total assets growth rates are significantly higher in U.S. and German manufacturing corporations than in Japanese manufacturing corporations. However, the differences are not statistically significant in U.S. and German manufacturing corporations.

\section{Summary and Conclusions}

In this paper, we compare the business management characteristics of U.S., German, and Japanese manufacturing corporations by using the MANOVA (Multivariate Analysis of Variance) technique with data from the Research Insight/Global Vintage database obtained in October 2017. The multivariate test statistics indicate that overall business management characteristics of U.S., German, and Japanese manufacturing corporations are significantly different. The uivariate test statistics show that a number of business management characteristics of U.S., German, and Japanese manufacturing corporations are significantly different. Our findings in this study may provide valuable insights for corporate managers and global investors.

Liquidity is significantly higher in U.S. manufacturing corporations than in German and Japanese manufacturing corporations (i.e., U.S. manufacturing corporations have significantly lower liquidity risk compared with German and Japanese manufacturing corporations). The equity/liabilities ratios are significantly lower in German manufacturing corporations than in U.S. and Japanese manufacturing corporations (i.e., German manufacturing corporations have greater bankruptcy risk compares with U.K. and Japanese manufacturing corporations). 
U.S. manufacturing corporations appear to have more efficient management of accounts receivable and accounts payable compared with their German and Japanese counterparts. The average collection period of accounts receivable and the average payment period of accounts payable are significantly shorter in U.S. manufacturing corporations than in German and Japanese manufacturing corporations. Due to the extensive use of the just-in-time inventory management system in keiretsu industry groupings, Japanese manufacturing corporations have higher inventory turnover rates (i.e., Japanese manufacturing corporations carry lower inventory levels) compared with U.S. and German manufacturing corporations.

U.S. manufacturing corporations are able to earn significantly higher operating profit margins compared with their German and Japanese counterparts because they are able to charge higher product prices to their customers and/or they are able to have lower manufacturing costs. Return on assets and return on equity are significantly higher in U.S. and German manufacturing corporations than in Japanese manufacturing corporations. Japanese manufacturing corporations have significantly lower annual sales and total assets growth rates compared with U.S. and German manufacturing corporations.

\section{References}

Altman, E. I. 1968. Financial Ratios, Discriminant Analysis, and the Prediction of Corporate Bankruptcy. Journal of Finance, 23 (4): 589-609.

Beaver, W. H. 1968. Alternative Financial Ratios as Predictors of Failure. Accounting Review, 43 (1): 113-122.

Belkaoui, A. 1978. Financial Ratios as Predictors of Canadian Takeovers. Journal of Business Finance and Accounting, 5 (1): 93-108.

Choi, F., and G. Meek. 2011. International Accounting. Pearson, 7th edition.

CIA World Fact book, 2018 (https://www.cia.gov/library/publications/resources/the-world-factbook)

Dambolena, I. G., and S. J. Khoury. 1980. Ratio Stability and Corporate Failure. Journal of Finance, 35 (4): 1017-1026.

Deakin, E. B. 1972. A Discriminant Analysis of Predictors of Business failure. Journal of Accounting Research, 10 (1): 167-179.

Economist. 1999. “Japan Restructures, Grudgingly." February 6: 63-65.

Edmister, R. O. 1972. An Empirical Test of Financial Ratio Analysis for Small Business Failure Prediction. Journal of Financial and Quantitative Analysis, 7 (2): 1477-1493.

Gadarowski, C., G. Meric, C. Welsh, and I. Meric. 2007. "Dividend Tax Cut and Security Prices: Examining the Effect of the Jobs and Growth Tax Relief Reconciliation Act of 2003." Financial Management 36(4): 89-106.

Herbei, I. 2015. "Essential Attributes of the Accounting Information in Applying the Financial Reporting Differences between IFRS and US GAAP," Studia Universitatis "Vasile Goldis" Arad - Economics Series, 25(1), 1-57.

http://www.ifrs.org

https://www.hp.jicpa.or.jp/english/accounting/standards/index.html

https://www.slideshare.net/waxy28/accounting-system-in-germany

https://www.asb.or.jp/en/jp-gaap/about.html

Hutchinson, P., I. Meric, and G. Meric. 1988. The Financial Characteristics of Small Firms which Achieve Quotation on the UK Unlisted Securities Market. Journal of Business Finance and Accounting, 15 (1): 9-19. 
Johnson, R. D., and D. W. Wichern. 2007. Applied Multivariate Statistical Analysis, $6^{\text {th }}$ ed. Englewood Cliffs, NJ: Prentice Hall.

Kester, W. C. 1986. Capital and Ownership Structure: A Comparison of United States and Japanese Manufacturing Firms. Financial Management, 15 (1): 5-16.

Marascuilo, L. A., and J. R. Levin. 1983. Multivariate Statistics in the Social Sciences. Monterey, California: Brooks/Cole Publishing Company.

Meric, G., J. T. Bentley, W. C. Mccall, and I. Meric. 2016. A Comparison of the Financial Characteristics of U.S. and European Manufacturing Firms. Studies in Business and Economics, 11 (2): 58-67.

Meric, G., L. Kyj, C. Welch, and I. Meric. 2000. A Comparison of the Financial Characteristics of Japanese Kieretsu-Affiliated and Independent Firms. Multinational Business Review, 8 (2): 26-30.

Meric, G., S. S. Leveen, and I. Meric. 1991. The Financial Characteristics of Commercial Banks Involved in Interstate Acquisitions. Financial Review, 26 (1): 75-90.

Meric, G., and I. Meric. 1992. A Comparison of the Financial Characteristics of Listed and Unlisted Companies. Mid-Western Journal of Business and Economics, 7 (1): 19-31.

Meric, I., H. E. Gishlick, C. W. McCall, and G. Meric. 2003. A Comparison of the Financial Characteristics of U.S. and Canadian Manufacturing Firms. Midwestern Business and Economic Review, 31 (1): 25-33.

Meric, I., and G. Meric. 1989. A Comparison of the Financial Characteristics of U.S. and Japanese Manufacturing Firms. Financial Management-FM Letters-, 18 (4): 9-10.

Meric, I., and G. Meric. 1994. A Comparison of the Financial Characteristics of United States and Japanese Manufacturing Firms. Global Finance Journal, 5 (1): 205-218.

Moyer, R. C. 1977. Forecasting Financial Failure: A Re-examination. Financial Management, 6 (1): 11-17.

Rege, U. P. 1984. Accounting Ratios to Locate Take-over Targets. Journal of Business Finance and Accounting, 11 (3): 301-311.

Stevens, D. L. 1973. Financial Characteristics of Merged Firms: A Multivariate Analysis. Journal of Financial and Quantitative Analysis, 8 (2): 149-158.

Wald, J. K. 1999. How Firm Characteristics Affect Capital Structure: An International Comparison. Journal of Financial Research, 22 (2): 161-187.

Wang, J., G. Meric, Z. Liu and I. Meric. 2009. "Stock Market Crashes, Firm Characteristics, and Stock Returns." Journal of Banking and Finance 33(9): 1563-1574. 